\title{
The Development of E-Learning Model for College Students in the Industrial Era 4.0
}

\author{
Surya Priyambudi $^{1} \quad$ M. Harist Murdani ${ }^{2}$ \\ 1.Faculty of Language and Literature, Wijaya Putra University \\ 2.Faculty of Engineering, Wijaya Putra University
}

\begin{abstract}
In this digital era, learning system in higher education in Indonesia has also shifted to the era of digitizing which is based on e-learning media. By the time, the Covid-19 pandemic has changed the education system in Indonesia, therefore the learning system of Higher Education is performed using online learning model by utilizing information technology. However, the Covid-19 pandemic was able to accelerate the Educational of Industrial Era 4.0 by combining automation technology with cyber technology. This is a trend of automation and data exchange in the technology of manufacturing. Lecturers and students can take advantage of technological developments such as computers, smartphones, internet, and e-learning as supporting media in online learning. One of the applications that can be used for online learning process is e-learning efront. E-learning efront is a Learning Management System that provides more display of interactive menus which can be adjusted for online learning of Indonesian Language courses in Wijaya Putra University. This paper is categorized as development research which aims to produce an online learning media for Indonesian Language course of Wijaya Putra University. Using Research and Development (R\&D) method, testing activities in this validation are performed by lecturers and students. The assessment instrument used in this validation process is a questionnaire. This research uses qualitative and quantitative data. Qualitative data is the responses given by validator (Head of the Major Program) in the form both critics and suggestion about the learning media that being developed. Meanwhile, quantitative data is an assessment of online learning model instrument by respondents (lecturers and students) that is pointed by scale 1 to 5. Research activity plans: 1) Analyzing the needs of lecturers and students, together with RPP (lesson plans) for Indonesian Language courses, 2) Designing storyboards of online learning efront, 3) Preparing the learning materials, exercises, application menus of online learning efront, 4) The use of application in the learning process between lecturers and students, as well as students give assessments and suggestions, and 5) Conducting and revising product trials of online learning media efront with an assessment by lecturers and students.
\end{abstract}

Keywords: E-learning, Online learning, Efront, Industry 4.0

DOI: $10.7176 / \mathrm{JEP} / 11-31-09$

Publication date: November $30^{\text {th }} 2020$

\section{INTRODUCTION}

Learning courses in University currently are shifting to the era of digitizing online learning media. In Indonesia, internet users, in general, have increased significantly, which twice form the number in the last five years. This data is according to e-Marker market research institution that showed the internet usage in Indonesia has reached number 6 of the world (K.K \& LR, 2018). Research institution of Hootsite and We Are Socia (H7W.A, 2019) said that daily internet access time of Indonesians is 8 hours 36 minutes.

By this time, Covid-19 pandemic has changed the education system in Indonesia, thus limiting human activities. However, this pandemic is able to accelerate the education system of Industrial Era 4.0. Learning system is conducted online by utilizing the information technology. Nevertheless, Higher Education is not yet accustomed to use a learning system that is blended and completely online. The use of information technology in the learning process is E-learning Efront as a learning model based on the virtual environment between lecturers and students. They can interact without having to meet face to face on campus and without worrying about space and time constraints.

Compared to the conventional learning model of Indonesian Language courses, online learning using $E$ learning Efront provides more benefits. According to Ahmed A, K, 2017, e-learning is an education system which delivers learning and electronic training involving computers and devices that connect to the internet (R. Khudhair \& A.Ahmed, 2017, pp 104-108).

Based on the background above, therefore the problem statements of online learning using efront to increase effectiveness and efficiency of college students learning model in the Industrial Era 4.0 and the obstacles that probably encounter online learning activities are made.

\section{REVIEW OF LITERATURE}

\subsection{Learning Management System E-learning Efront}

E-learning is an educational system or concept that utilizes the information technology in teaching and learning process. Here are some understandings of E-learning from various sources: 
1) Learning system which is structured with the aim of using an electronic or computer system to support the learning process (M. Allen, 2013).

2) The distance learning process by combining the principles of learning process with technology (S.R. Chandrawati, 2010).

3) A learning system which uses electronic devices as the media (Gartika \& Rita, 2013). According to Wahono (M. Agustina \& A.M.Bakti, 2015), some components that are required for e-learningbased are:

1) Infrastructure Condition

The infrastructure needs for web-based learning activities includes: computers/laptops, internet networks, and multimedia equipment.

2) Software of Web E-learning

A web e-learning is usually built using a software or known as Learning Management System (LMS). Currently, the information and communication technology industry has developed a variety of web software that all the features are expected to meet all the needs of educational personnel in planning, conducting, and documenting learning activities, as well as conducting assessments and all things commonly done in conventional classrooms.

3) Content of Web E-learning

Web e-learning must-have features that can manage various learning materials that can be accessed from any time with any internet-connected device. The content can be in the form of web pages, audio media, videos, images, interactive multimedia, files, etc.

According to Wikipedia (elearning software): "eFront is an eLearning platform (also known as a Course Management System (CMS), or Learning Management Systems (LMS), or Virtual Learning Environment (VLE)). eFront has historically been coming in a number of editions, from an open-source edition to the latest eFront Pro edition.

eFront is designed to assist with the creation of online learning communities while offering various opportunities for collaboration and interaction through an icon-based user interface. The platform offers tools for content creation, tests building, assignments management, reporting, internal messaging, forum, chat, surveys, calendar and others. It is a SCORM 1.2 certified and SCORM 2004 / 4th edition compliant system translated in 40 languages.

eFront is commonly included in lists of well known open-source learning systems or is referred to as a Moodle alternative. Independent comparison matrices between learning management systems often favour eFront, especially under usability characteristics. Several research papers and technology portals describe the system under functionality, usability and standards perspectives."

Efront learning is known as an integrated learning management system to ease lecturers and students in teaching and learning process. Efront is designed to create a variety of interactions of online learning. Efront is generally part of open source software list that can be easily developed to be more attractive. The main difference between efront and other LMS is the better menu management because the interface and menus between admin, lecturers, and students are not similar. Below are the advantages of using Efront:

1) Well supported: Efront is a program that is professionally designed and supported by other devices. Although there is an old design of efront, but everyone can use it easily;

2) Easy to use: Efront is designed to stimulate knowledge so that it is easier for users to use and utilize the available facilities;

3) Open for public: Efront is Learning Management System (LMS) platform which is open to public, so that users can be benefitted in using efront facilities openly. 


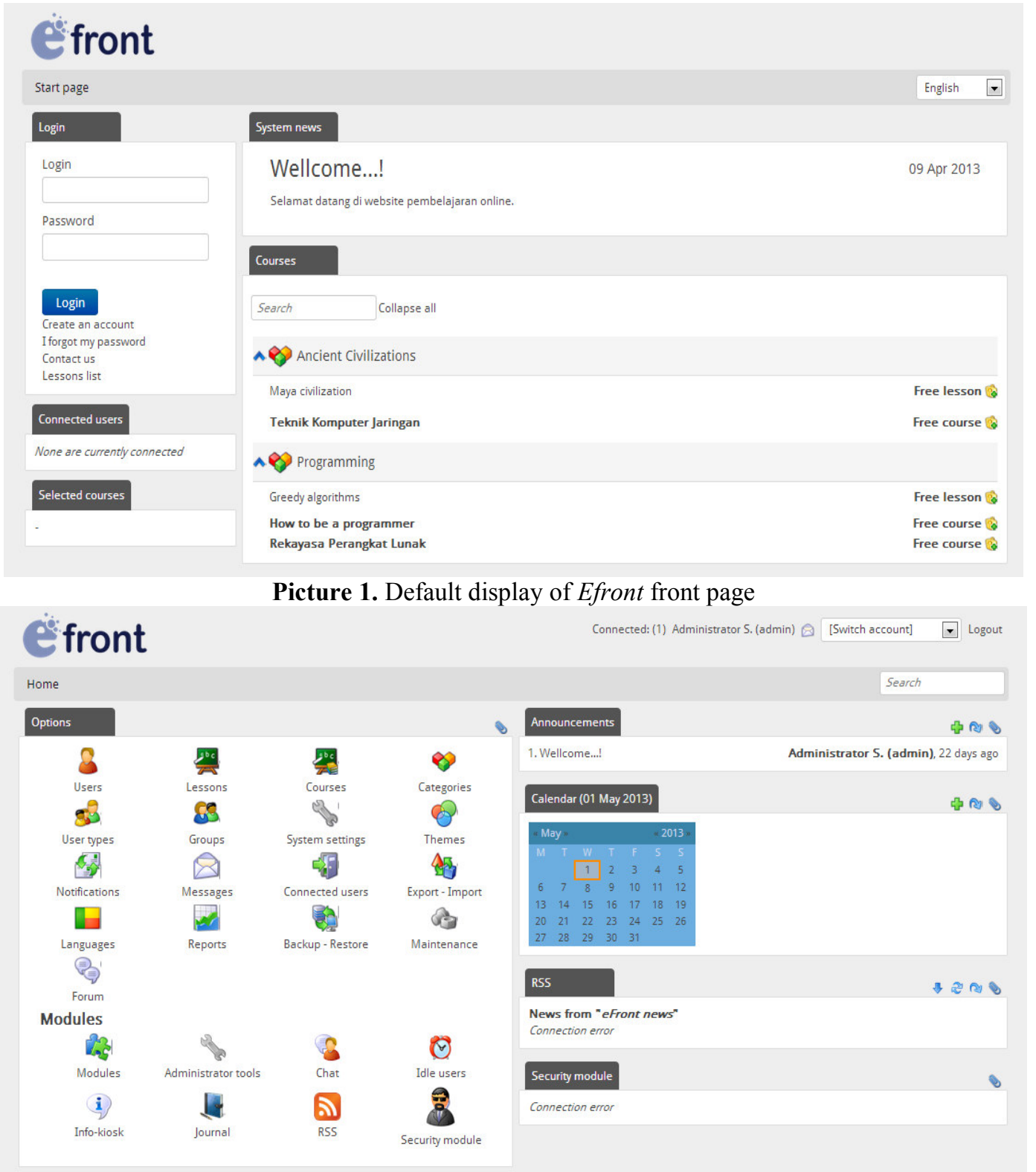

Picture 2. Administration page of Efront

\subsection{Online Learning of College Students}

Online learning process for college students helps them to develop their soft skills and deeper learning experiences. This learning model is similar to Deep Learning model. (Eric Jensen \& LeAnn Nickelsen, 2011) stated that Deep Learning is the acquisition of new content or skill that must be learned in more than one step and with multilevel of analysing or processing. With this, a student can apply contents or skills by changing their thoughts, influences, or behaviours.

However, with more efforts in learning, it does not mean that it can be used as a deficiency but can be turned into added value for students to develop their abilities in gaining real experience. With a strong foundation, students can explore themselves further in learning to improve their abilities based on their respective talents and majors.

\subsection{Learning Model for College in the Industrial Era 4.0}

The Industrial Revolution 4.0 is generally known as a change in working methods that emphasizes data management, industrial work systems through technological advances, communication, and efficiency work increasing related to human interaction. University is a formal institution that is expected to produce competent workers who are ready to face the work industry which is increasingly developed along with the technological advances. Work skills, adaptability, and a dynamic mindset are challenges for human resources that can be obtained while informal education, i.e University.

The policies of Higher Education in the industrial revolution 4.0 are (Ardian \& Nita, 2019): 
1) The Tri Darma of University paradigm must be accelerated with the industrial era 4.0.

2) Curriculum Reorientation:

a. New literacy (big data, technology or coding, humanities) is developed and taught.

b. Extra-curricular activities for leadership development and team work continously being developed.

c. Entrepreneurship and internship are required.

3) E-learning applies hybrid/bleanded online learning and teaching system.

4) Grants and Bimtek (technical guidance) from Belmawa for curriculum reorientation (GENRI 4.0) for 400 PT.

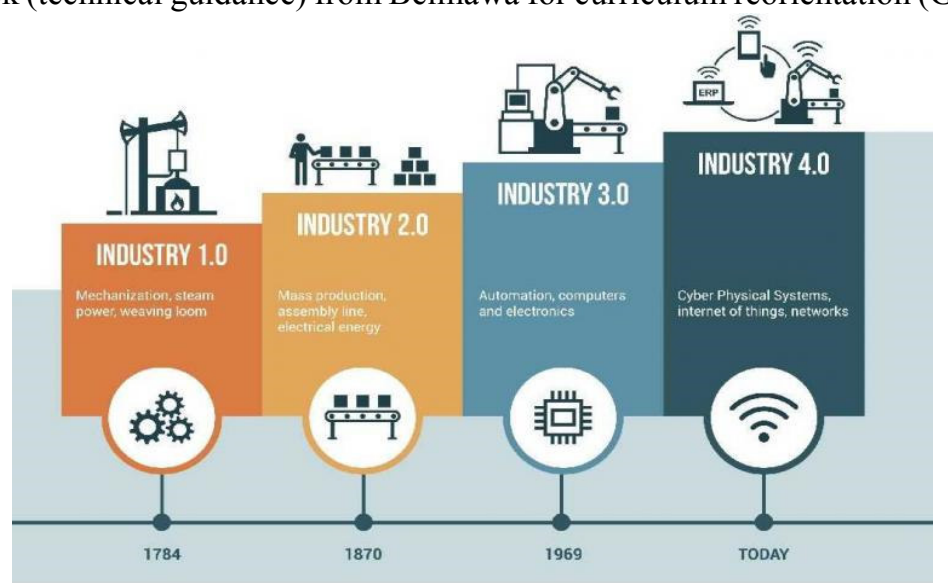

Picture 3. Industrial Revolution 4.0 (http://www.aberdeenessentials.com)

Online lecture is a learning system that can be done anytime and anywhere by utilizing the information technology via smartphones, gadgets, or laptops and the internet. Lecturers no longer have to enter conventional classes nor being concerned about lag learning to students. The online lecture also can provide solutions for a university that have a large number of students but do not have adequate classrooms or are insufficient to accommodate students in order to perform teaching and learning process. The online lecture has received positive support from the Ministry of Research, Technology and Higher Education (Kemeristekdikti) to encourage economic growth of the nation's competitiveness in the era of Industrial Revolution 4.0.

\section{RESEARCH METHODOLOGY}

\subsection{Model Development}

This paper is categorized as development research that aims to produce a proper online learning media for Indonesian Language courses at Wijaya Putra University. The use of efront eases the lecturers to pack more interactive online learning by referring to the effectiveness and efficiency of its use. "The research method is a scientific way to obtain data with specific purposes and uses (Sugiyono, 2015)."

\subsection{Stage of Modelling / Product}

This research uses Research and Development ( $\& \& D)$ methodology in developing online learning media for Indonesian Language courses at Wijaya Putra University. Research and Development (R\&D) methodology is a research method which is used to develop or validate products in education and learning field (Hanafi, 2017). By using ADDIE approach model that is easy to use and can be applied in the curriculum of knowledge, skills, or attitudes. (Cheung, 2016).

The following stages are performed as given below:

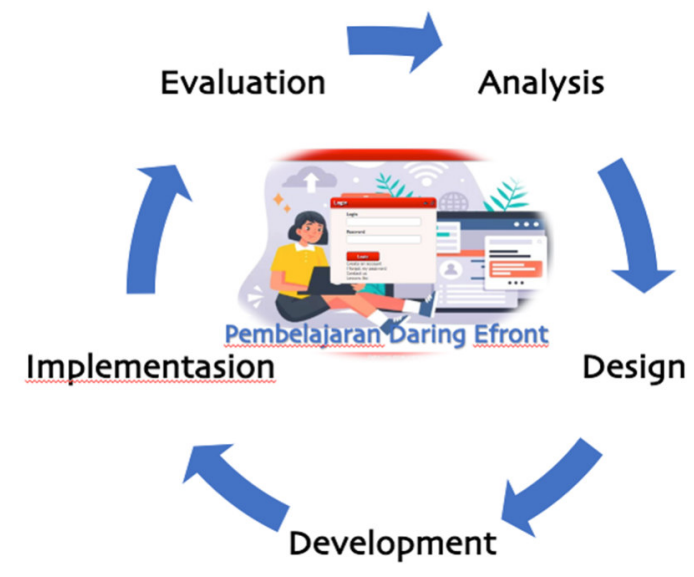




\subsection{Model / Product Test}

The online learning model using efront application is conducted for Indonesian Language courses. Testing activities in this validation is performed by lecturers and students. A questionnaire is used as the assessment instrument. Product testing activities are systematically stated as follows:

1) Design Testing

Design trials of the development of learning media include:

a. Individual trials of the development are performed by Indonesian Language lecturers.

b. Group trials are performed by students to determine whether the online learning model is interesting, responding, and interactive.

2) Subject Testing

The requirement specified in the selection of subject data are users of online learning media who use the efront application i.e lecturers of Indonesian Language courses at Wijaya Putra University.

\section{3) Data Types and Instrumental}

The types of data that are used in this research are qualitative and quantitative. Qualitative data is an assessment of the online learning model instrument by lecturers and student from 1 to 5 . The data analysis used is preexperimental design single group Pre-Test Post-Test. The Pre-Test and Post-Test are put to measure the efficiency of using e-learning efront.

Qualitative data is the responses given by the validator (Head of the Major Program) in the form of critics and suggestions about online learning media using efront application. Qualitative data is the result of quantitative data that is obtained through the assessment instruments that are converted on a scale 1 to 5 . Then the result of the description are used as a basis for assessing the quality of the learning model that is being developed.

\section{4) Data Collection Instrument}

The data collection instrument used is a closed-ended questions - is a questionnaire that have provided choices, then only check mark $(\sqrt{ })$ is needed to put in the column that has been provided. There are 2 types of instrument that is used based on the respondents, i.e questionnaire for lecturers and students.

\section{RESULTS OF MODEL/PRODUCT}

\subsection{Data Presentation}

The data presentation describes the results of responses or assessments by lecturers and students.

Lecturer Trial

The material suitability test is performed by the lecturers of Indonesian Language courses at Wijaya Putra University.

Table 1. Results of Assessments/Responses

\begin{tabular}{|c|l|c|}
\hline No & \multicolumn{1}{|c|}{ Assessment Component } & Scale \\
\hline 1 & The clarity of lesson identities. & 5 \\
\hline 2 & The suitability of material with Competency Standards and Basic Competency. & 5 \\
\hline 3 & The suitability of learning material topics with RPS (Semester Lesson Plan). & 4 \\
\hline 4 & The suitability of presentation order of teaching material. & 4 \\
\hline 5 & The clarity of language that is being used. & 5 \\
\hline 6 & The clarity of instructions that is being used. & 5 \\
\hline 7 & The suitability of the use with the students' ability. & 4 \\
\hline 8 & Helping the effectiveness of learning. & 5 \\
\hline 9 & Able to use as a suplement in learning activities. & 5 \\
\hline 10 & Able to complete subject matter that has a wide range of material. & 5 \\
\hline 11 & The clarity of instructions description. & 4 \\
\hline 12 & Learning material access requires particular prerequisites. & 5 \\
\hline 13 & The suitability of time allocation for learning material access. & 4 \\
\hline 14 & The suitability of digital tectbooks with learning materials. & 5 \\
\hline 15 & An attractive digital textbooks. & 4 \\
\hline 16 & The suitability of questions to the learning material. & 5 \\
\hline 17 & The suitability of the assessment to the learning material assignments. & 5 \\
\hline 18 & The availability of space for question and answer discussion in chat or forum. & 4 \\
\hline \multicolumn{1}{|c|}{ Total } & $\mathbf{8 0}$ \\
\hline
\end{tabular}

The comments given by the lecturers are the design of learning media that has been prepared and can be used for Indonesian Language courses materials. Based on the interview regarding to the responses, it showed that efront online learning model application is appropriate and attractive for lessons at the college level.

College Trial 
The implementation of online lecture trial is performed by Indonesian Language lecturers accompanied by developers. Indonesia Language lecturers conduct a learning process for Indonesia Language courses. The lecturers prepare materials and exercises on Efront but firstly log in using the lecturers access rights found within the application.

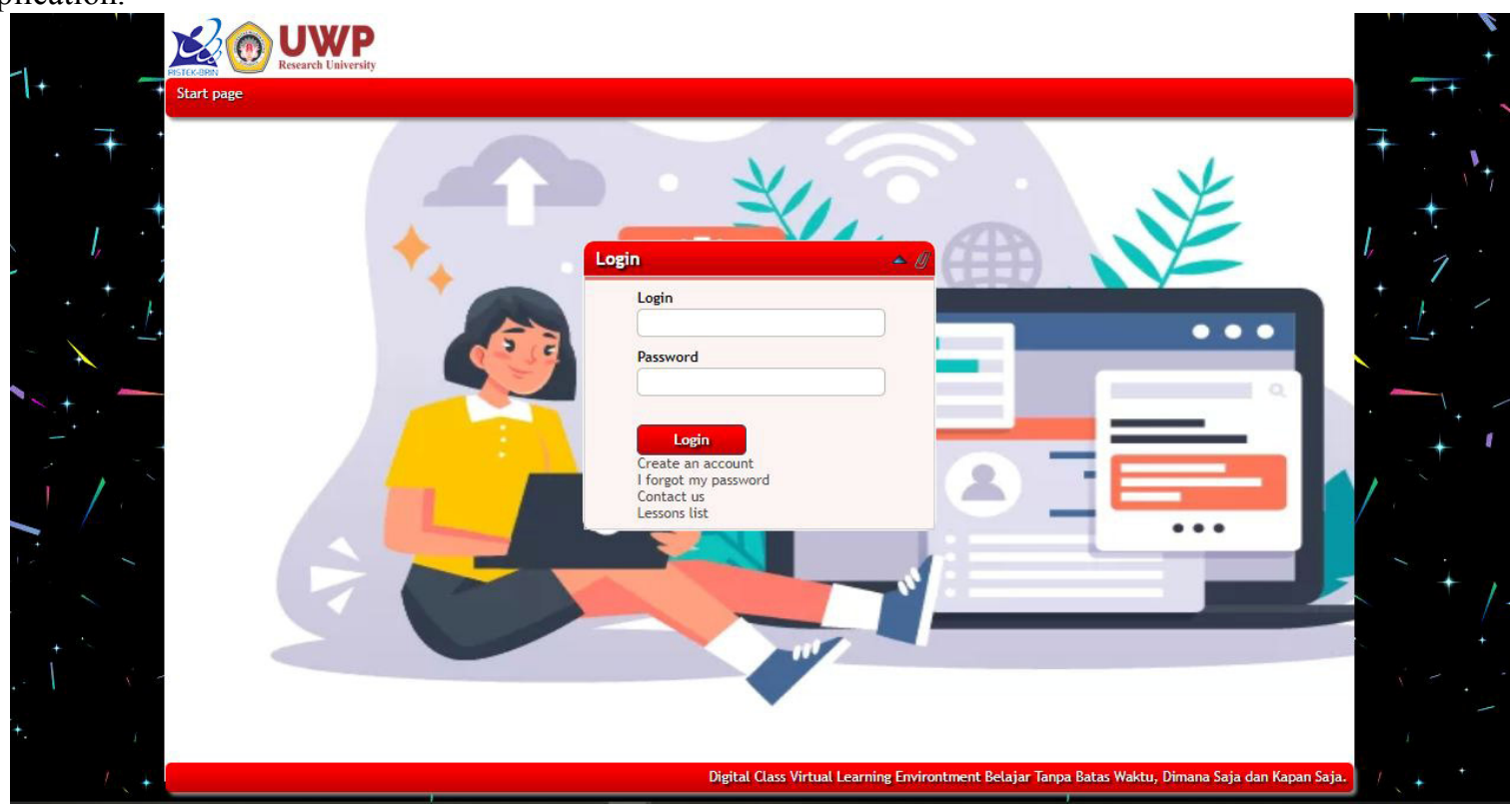

Image 4. Login Menu of Online Learning

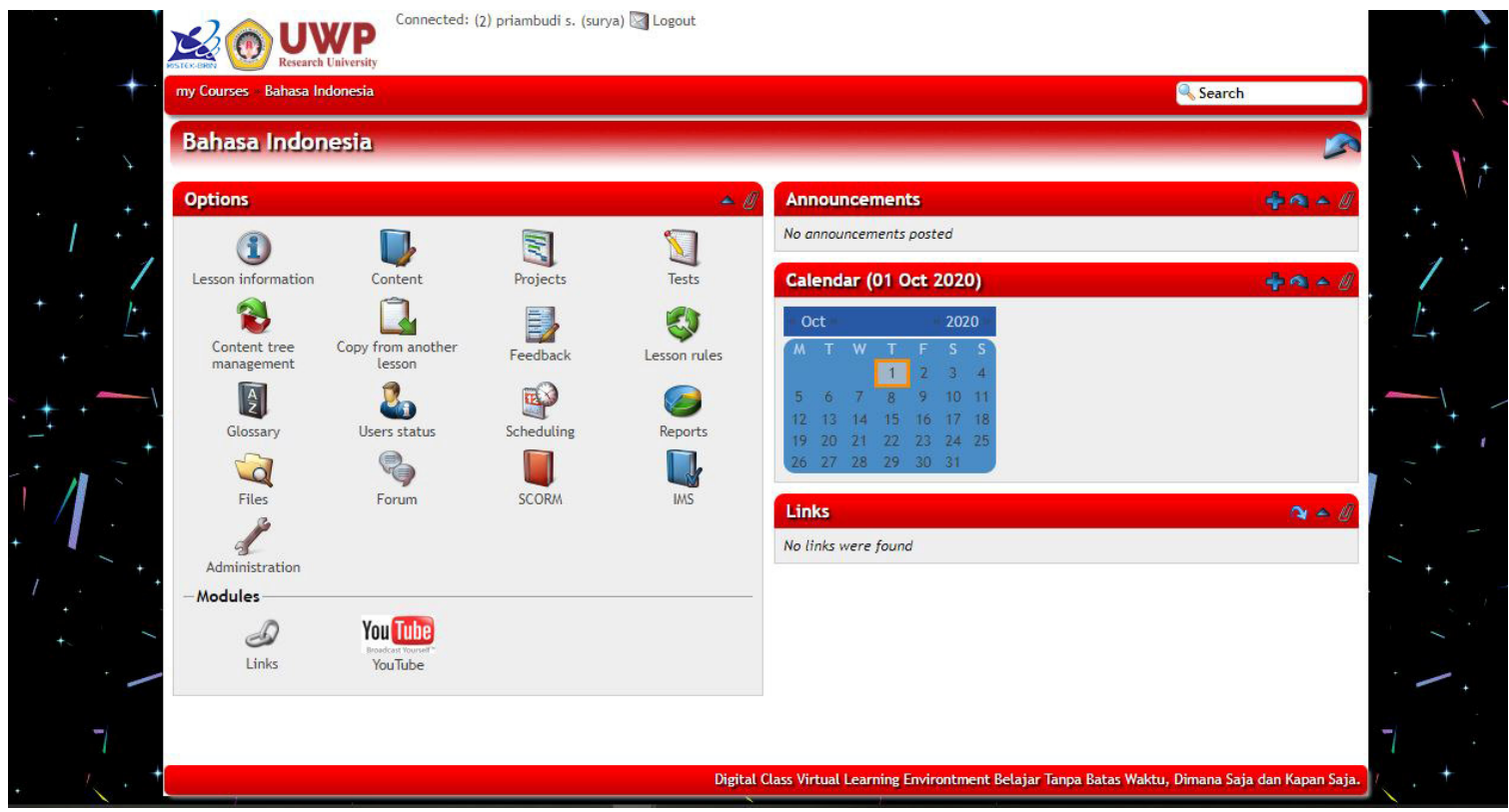

Image 5. Lecturer Display Menu

Students $\log$ in with the agreed time according to lecture schedule. Before the learning process begins, students are required to read the guidance of using Efront application to obtain students access rights that can be downloaded on the start screen of Efront application. Students choose the Indonesian Language courses menu. First, students read the digital books of the subject before working on the exercises that have been provided by the lecturer. This is the requirement. In order to do the assignments, students must read or download the book first. 


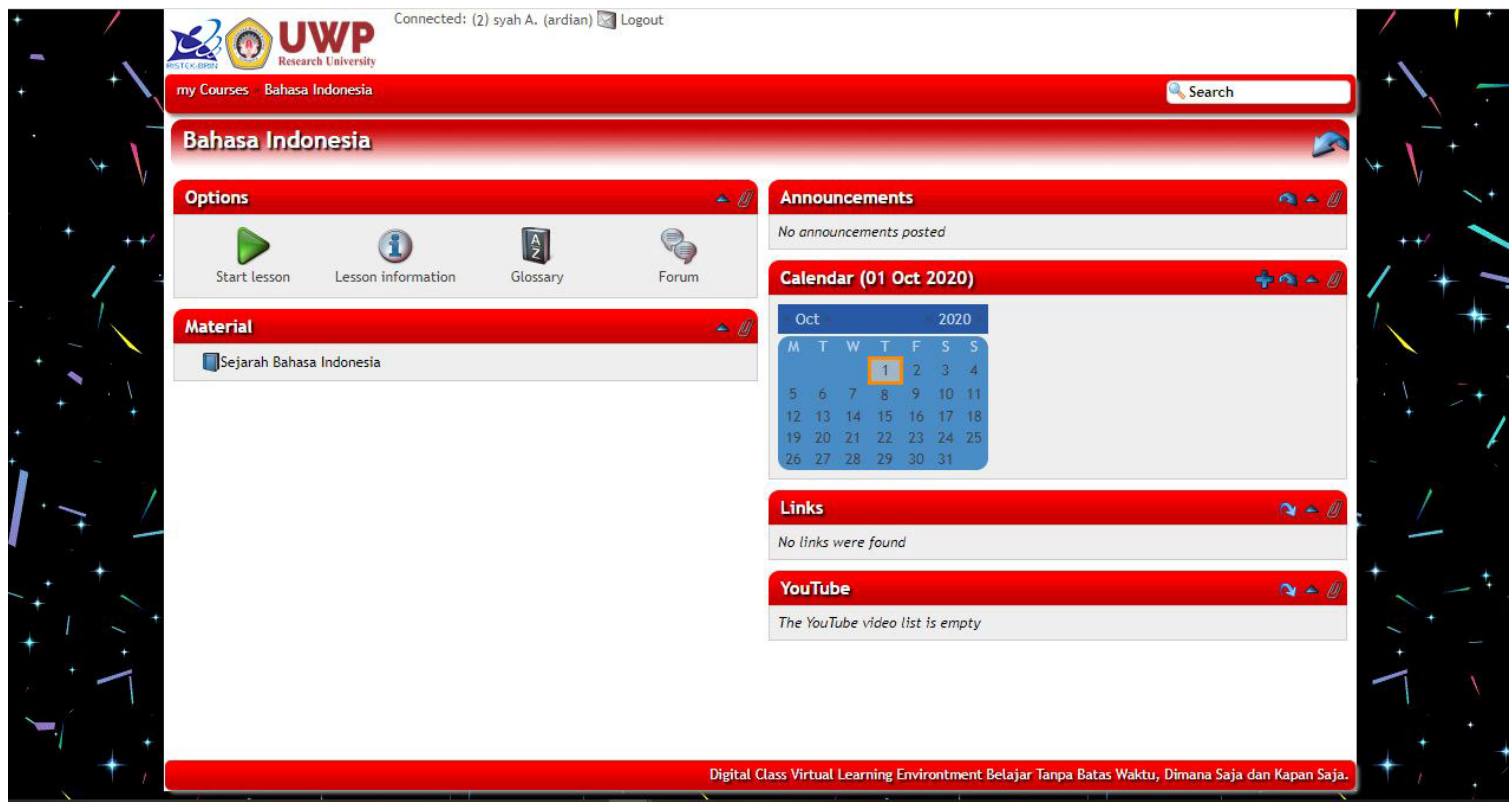

Picture 6. Student Display Menu

Lecturer can immediately correct and assess the students' assignments on Efront application, therefore students can immediately find out the score of the assignment they have done. Lecturers give assignments to students with the time limit that has been set in Efront application, so that the exercises will automatically start and end by the time set.

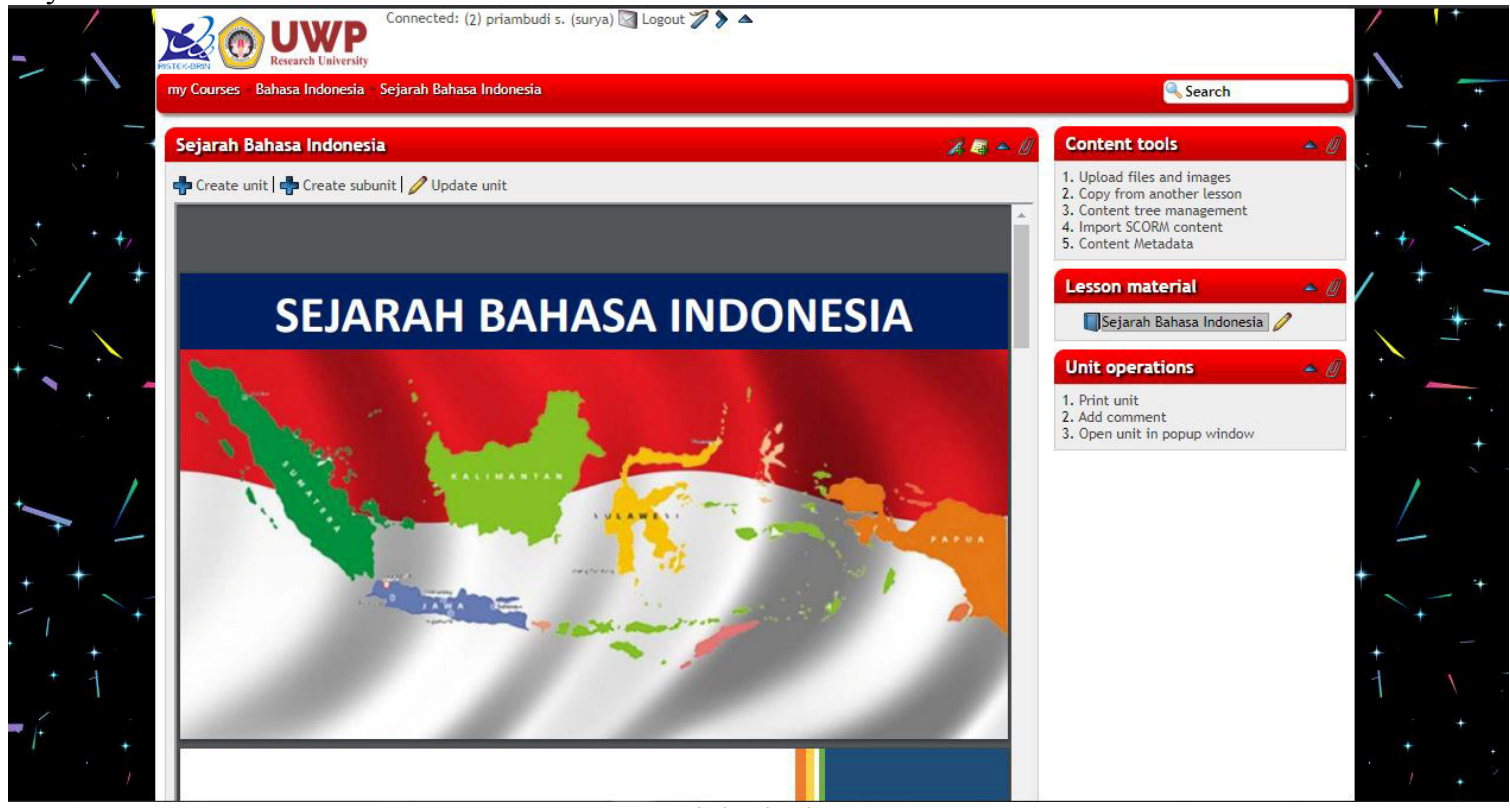

Picture 7. Material Display Menu 


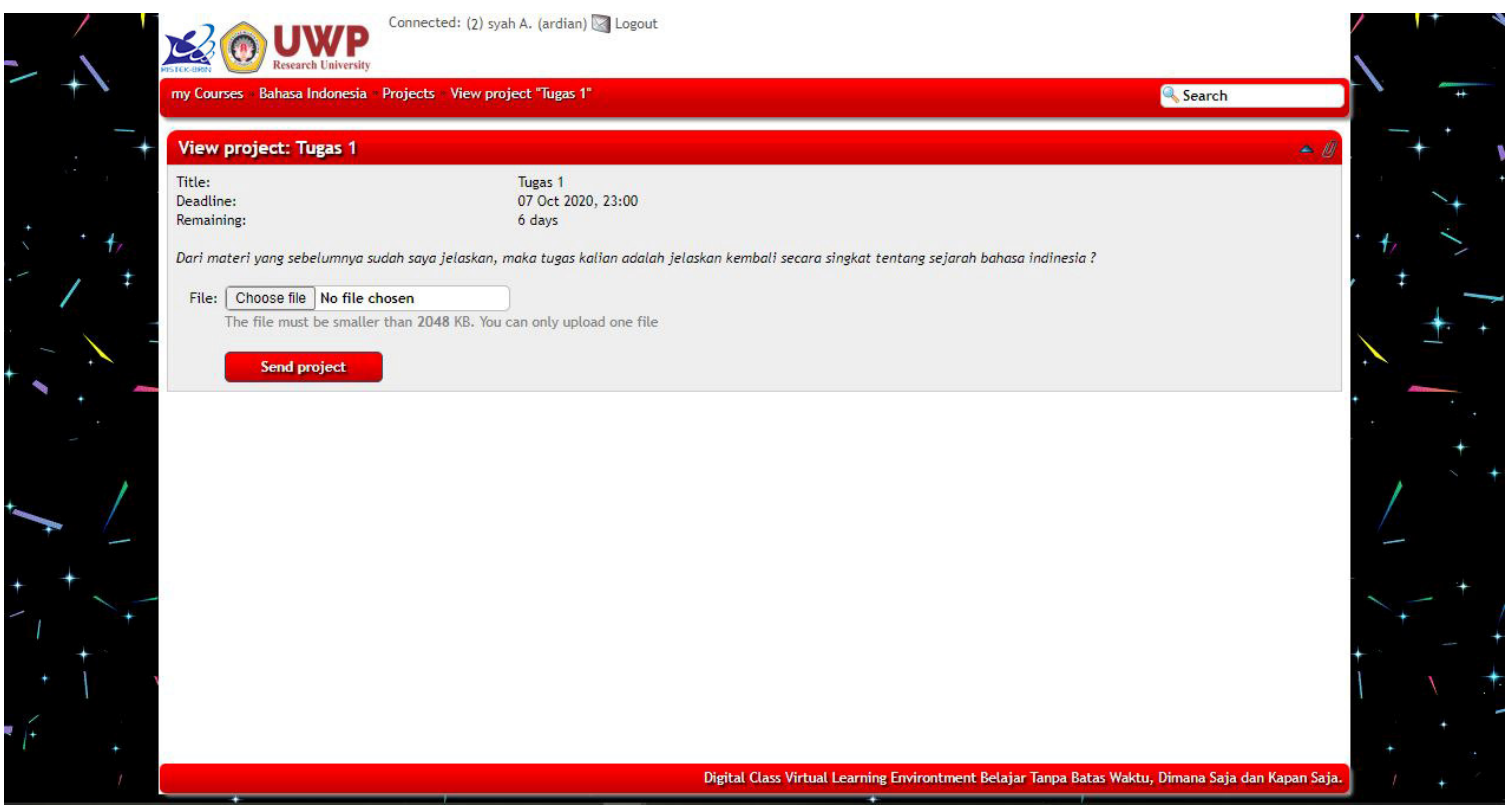

Picture 8. Assignment Display Menu

Students can ask the lecturer about the material through the chat menu. And if they want to discuss with other students, they can choose the forum menu. Video conference menu also has been provided for lecturing activities to be more interactive.

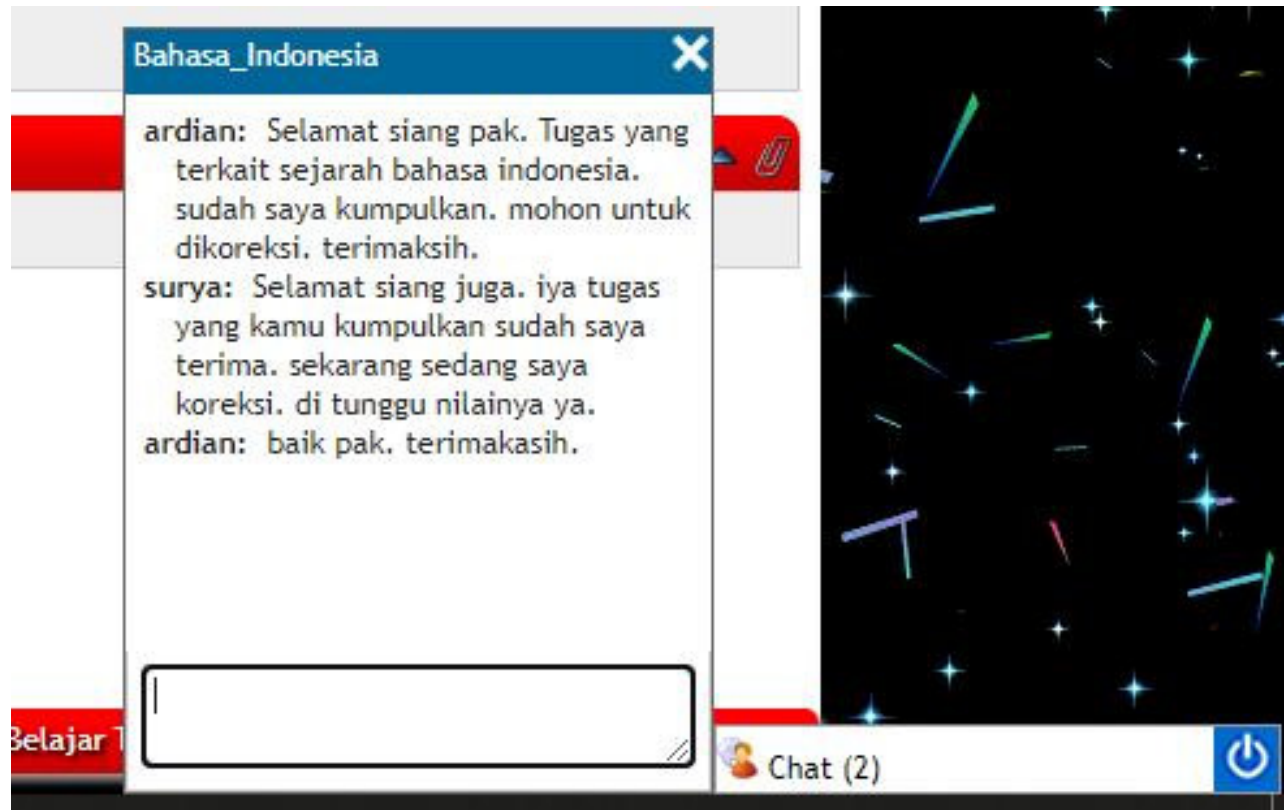

Picture 9. Chatroom Display Menu 


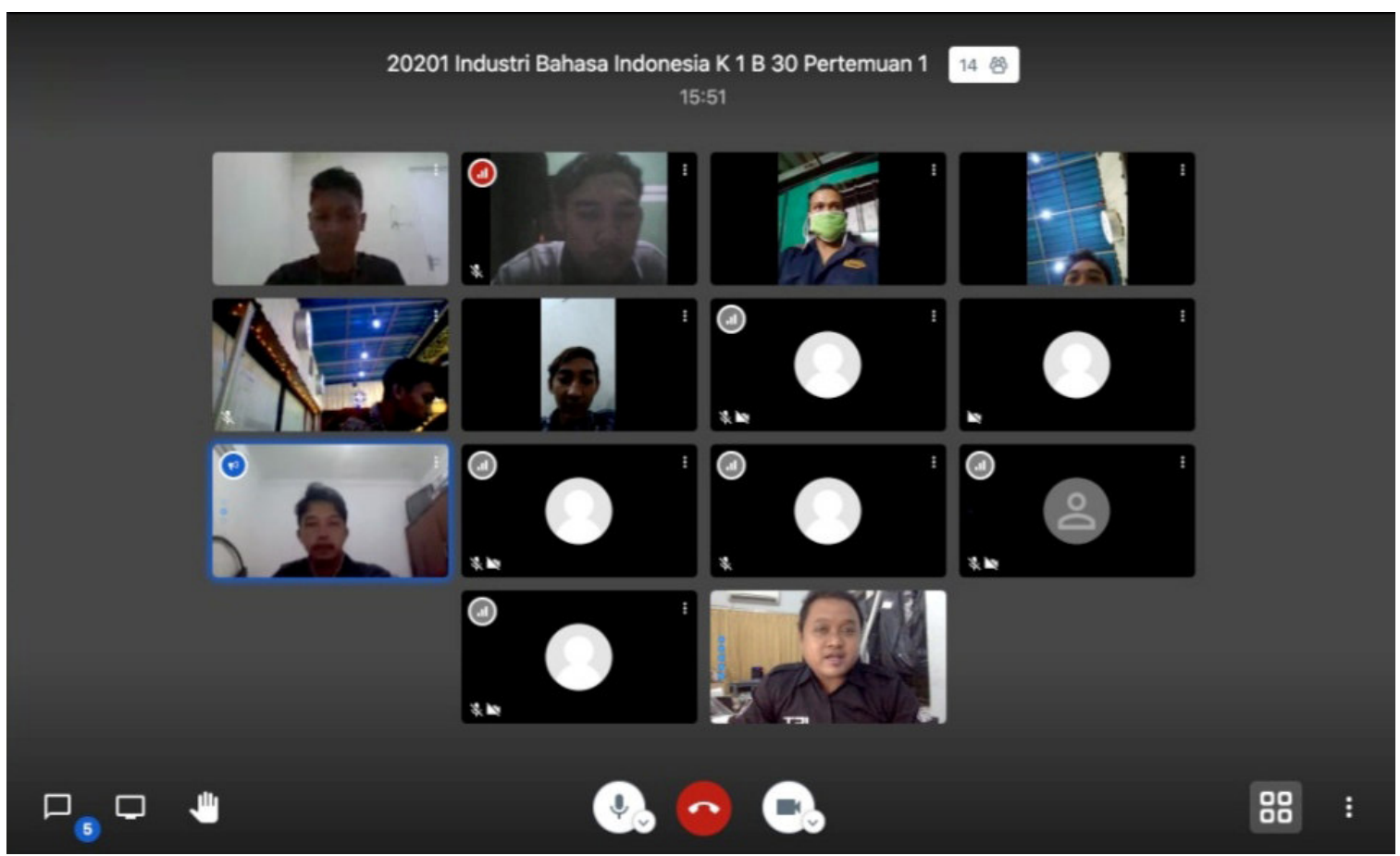

Picture 10. Video Confrence Display Menu

Recapitulation Table of Students' Responses to Media

\begin{tabular}{|c|c|c|c|c|c|c|c|c|c|c|}
\hline \multirow{2}{*}{ Assessment Component } & \multicolumn{8}{|c|}{ Respondents } & \multirow{2}{*}{$\begin{array}{l}\text { Total } \\
\text { Score }\end{array}$} & \multirow{2}{*}{$\%$} \\
\hline & 1 & 2 & 3 & 4 & 5 & 6 & 7 & 8 & & \\
\hline $\begin{array}{l}\text { The use of Efront application to lecture materials is } \\
\text { something new for you. }\end{array}$ & 4 & 5 & 5 & 5 & 5 & 5 & 4 & 5 & 38 & 95 \\
\hline $\begin{array}{l}\text { Obtain a pleasant experience in learning Indonesian } \\
\text { language using Efront application. }\end{array}$ & 5 & 4 & 5 & 5 & 4 & 5 & 5 & 5 & 38 & 95 \\
\hline $\begin{array}{l}\text { The instructions for using Efront application is easy } \\
\text { to understand. }\end{array}$ & 5 & 5 & 5 & 5 & 5 & 5 & 5 & 5 & 40 & 100 \\
\hline $\begin{array}{l}\text { Obtain an easy understanding of materials through } \\
\text { Efront application. }\end{array}$ & 5 & 4 & 5 & 4 & 5 & 3 & 4 & 4 & 34 & 85 \\
\hline $\begin{array}{l}\text { The language used on the menu of Efront application } \\
\text { is easy to understand. }\end{array}$ & 4 & 5 & 4 & 5 & 5 & 4 & 5 & 5 & 37 & 92,5 \\
\hline Obtain an easy independent study. & 5 & 5 & 5 & 5 & 4 & 4 & 4 & 5 & 37 & 92,5 \\
\hline The diplay of Efront application is attractive. & 5 & 5 & 5 & 4 & 5 & 5 & 5 & 5 & 39 & 97,5 \\
\hline $\begin{array}{l}\text { The menu of Efront application is easy to to use or } \\
\text { operate. }\end{array}$ & 5 & 5 & 5 & 5 & 5 & 5 & 5 & 5 & 40 & 100 \\
\hline $\begin{array}{l}\text { Course materials is easy to be discussed through } \\
\text { forums and chat. }\end{array}$ & 5 & 5 & 5 & 5 & 4 & 5 & 4 & 4 & 37 & 92,5 \\
\hline $\begin{array}{l}\text { Efront application is easy to be accessed in } \\
\text { computers, laptops, tablets, and handphones. }\end{array}$ & 5 & 5 & 4 & 4 & 5 & 5 & 5 & 5 & 38 & 95 \\
\hline The effectiveness of using Efront application. & 5 & 5 & 5 & 5 & 5 & 5 & 5 & 5 & 40 & 100 \\
\hline Total & 58 & 58 & 58 & 57 & 57 & 56 & 56 & 58 & 458 & \\
\hline Percentage & 96 & 96 & 96 & 95 & 95 & 93 & 93 & 96 & 95 & \\
\hline
\end{tabular}

Comments or suggestions by students during the lecture trial using Efront application are presented in the following table: 
Table of Students' Comments/Suggestions during Lecture Trial

\begin{tabular}{|c|l|c|}
\hline No & \multicolumn{1}{|c|}{ Comments/Suggestions } & Respondents \\
\hline 1 & Online assignements are more interesting. & R1 \\
\hline 2 & $\begin{array}{l}\text { The guide to use Efront application is quite clear, so it is not confusing to use the } \\
\text { application. }\end{array}$ & R2 \\
\hline 3 & The program is effective and can be accessed via handphone anytime. & R3 \\
\hline 4 & $\begin{array}{l}\text { The program is good and all students can be able to study with modern Efront } \\
\text { application. }\end{array}$ & R4 \\
\hline 5 & Th language menu in Efront application can be changed. & R6 \\
\hline 6 & $\begin{array}{l}\text { The use of mobile phone for independent study through Efront application is more } \\
\text { exciting. }\end{array}$ & R7 \\
\hline 7 & The score of assignments can be seen immediately, the program is online. & $\mathrm{R} 8$ \\
\hline 8 & It will be more exciting if all courses using Efront application. & \\
\hline
\end{tabular}

\subsection{Data Analysis}

Data analysis of the assessments of lecturer trial and student trial are used to determine the eligibility level of the product/media that has been tested. By this, the analyzed data is matched with predetermined eligibility table.

\section{Lccturer Individual Trial}

The results of the lecturer assessments can be calculated and the achievement level is $92 \%$. Based on the eligibility conversion table, $92 \%$ of achievement level is a very good qualification. This means that Efront-based learning model is very effective for college students.

The results of Wijaya Putra University lecturers can be calculated and the achievement level is $94 \%$. Based on the eligibility conversion table, $94 \%$ of achievement level is a very good qualification. This means that Efrontbased learning model is very good for college students.

\section{Lecture Trial}

Data analysis is conducted to determine the average percentage of the lecture trial results, the average percentage of evaluation tools is: $(96+96+95+95+93+93+96+95) \%: 8=95 \%$. The average percentage of evaluation tools is $95 \%$. Based on the eligibility conversion table, this category is very good and appropriate for college students, therefore it does not need any revision.

\subsection{Product Verification / Revision}

Based on the results of individual trial assessment performed by lecturers of Indonesian Language courses, the use of Efront application in online learning does not need to be revised because the percentage of the achievement level of eligibility for Indonesian Language courses has already in a good category. The sugesstion from lecturers about providing materials, exercises, and video conferences are not really complicated because the menu of Efront application can use Indonesian. It can provide efficiency for the lecturers. Based on data analysis taken from students, it is known that the overall assessment of Efront-based online learning model is in good category and does not need to be revised. The suggestion from students about learning process using Efront application are more effective, because lecturing activities can be done anywhere with internet connection and handphone.

\section{CONCLUSION AND SUGGESTION}

\section{Conclusion}

After presenting and analyzing data about the implementation of research and development of online learning models based on Efront in Indonesian Language courses to increase the effectiveness and efficiency of lecturing activities, it can be concluded:

1. The implementation of Indonesian Language courses using Efront-based online learning model went well with a very good product quality.

2. The result of this research indicated that Efront-based online learning model can increase the effectiveness and efficiency of lecturing activity of college students.

\section{Suggestion}

1. The implementation of the developed evaluation product needs to be performed on a wider sample.

2. Provision of supporting facilities and infrastructure such as hardware and internet networks, considering that generally the use of Efront application is performed by many people. Therefore, there is a need for internet access on a server that must always be on.

3. The need for more attractive teaching material design, so that the students are more excited and enthusiastic 
to read the materials in Efront application.

\section{References}

Ardian Syaputra and Nita Nurita, "Ministry of Research Technology and Higher Education: Policies of Higher Education must be Relevant with Industrial Revolution 4.0," 2018. https://ristekdikti.go.id/kabar/menristekdikti-kebijakan-pendidikan-tinggi-harus-relevan-dengan-revolusiindustri-4-0/ (accessed Apr. 12, 2019).

B S, Heri Tri Luqman and Anies Erfan Dinarin B. 2013. E-Learning Development. Yogyakarta: Deepublish.

Cheung, L. (2016). Using ADDIE model of instructional design to teach chest radiograph interpretation. Journal of Biomedical Education 2016.

Courts, B., \& Tucker, J. (2012). Using Technology To Create A Dynamic Classroom Experience. Journal of College Teaching \& Learning (TLC), 9(2), 121-128

Efront. Your New Learning Management System, Less Hassle, More Result. diunduh dari http://www.Efrontlearning.net/

E. Jensen, B. Molan, and L. Nickelsen, Deeper Learning : 7 extraordinary strategies for deep and unforgettable learning / Eric Jensen, Leann Nickelsen ; translator, Benyamin Molan ; editor, Tim Indeks. Jakarta: Indeks, 2011 .

Feri.(2012). History of E-Learning Development. [Online].Tersedia: Http://e dufiesta.blogspot. com/2008/06/sejarah-perkembangan-e-learning.html

Gartika Rahmasari dan Rita Rismiati, E-learning in Senior High School. Bandung: Yrama Widya, 2013.

Hanafi, "Research Concept of $R \& D$ in Education Field," Saintifika Islam. J. Kaji. Keislam., vol. 4, no. 2, pp. 129-150, 2017.

Horton, W.K. (2012). E-Learning by Design. San Fransisco: Pfeiffer

H. \& W. A. Social, “Indonesian Digital Report 2019," 2019. https://datareportal.com/reports/digital-2019indonesia.

K. K. and I. R. Indonesia, "Indonesian Internet Users is World Number Six," 2018. https://kominfo.go.id/content/detail/4286/pengguna-internet-indonesia-nomor-enam-dunia/0/sorotan media

M. Agustina and A. M. Bakti, “(E-learning Readiness) Bina Darma University as Distance Learning Media,” pp. 123-132, 2015.

M. Allen, Michael Allen's Guide to E-learning. John Wiley \& Sons, 2013.

Pratama, M. Octaviano. 2012. Online Learning System with E-Learning Efront (Bagian-1). (Online), http://ilmukomputer.org/wp- content/uploads/2012/12/octav-SistemPembelajaranOnlineEfront.pdf,

"Industrial Revolution 4.0, Threats or Blessings?" http://www.aberdeenessentials.com/.

R. Khudhair and A. Ahmed, "Artificial Neural Networks in E-Learning Personalization : A Review," vol. 5, no. 6, pp. 104-108, 2017, doi: 10.11648/j.ijiis.20160506.14.

S. R. Chandrawati, “The Use of E-Learning," J. Cakrawala Kependidikan, vol. 8, no. 2, 2010, [Online]. Available: http://jurnal.untan.ac.id/.

Sugiyono, Educational Research Methods (Qualitative, Quantitative, and R\&D). Bandung: CV. Alfabeta, 2015.

Syaodih, Nana. 2010. Educational Research Methods. Bandung: PT. Remaja Rosdakarya.

Wibisono, Pradipha Wisnu. 2012. Online Learning (E-learning). downloaded from http://www.pradipha.com/2012/01/online-learning-e-learning.html pada tanggal 9 September 2013.

Wikipedia, "Efront Learning," 2018. https://en.wikipedia.org/wiki/EFront_(eLearning_software)\#cite_note-19 (accessed Apr. 12, 2019). 